\title{
Erratum - History of renal transplantation
}

Cite as: Can Urol Assoc J 2021;15(2):E129. http://dx.doi.org/10.5489/cuaj.7159

n the paper entitled, "The history of renal transplantation in Canada: A urologic perspective," published in in the December 2020 issue of CUAJ (Citation: Levine MA, Chin JL, Rasmussen A, et al. Can Urol Assoc J 2020;14(12):372-9. http://dx.doi. org/10.5489/cuaj.6744), in the list of urologists who helped launch successful kidney transplant programs in centers across the country, Dr. Vince Colapinto (St. Michael's Hospital, Toronto) was mistakenly referred to as Nick Colapinto.

CUAJ regrets the oversight and apologizes for any inconvenience. Visit https://cuaj.ca/index.php/journal/article/ view/6744/4697 for a corrected version of the paper. 